\title{
Instructional Leadership in Malaysia
}

\author{
Roslizam Bin Hassan, Jamilah Ahmad, Yusof Boon
}

\begin{abstract}
Leadership of school leaders regardless principals or headmasters is among the key factors that can affect the academic achievement of students directly or indirectly. Based on previous research, a strong relationship between student achievement and leadership of school leaders was proven. The Ministry of Education Malaysia (MoE) has outlined three approaches to improving student achievement through the improvement of school leaders' performance. One of the approaches is school leaders should act as instructional leaders who are actively involved in teacher development activities by planning, coordinating and evaluating the teaching and learning process $(T \& L)$ at school. This concept paper will discuss several matters related to instructional leadership such as background and development of instructional leadership, instructional leadership definitions, the development of instructional leadership concepts, instructional leadership models and the issues and challenges that exist in implementing this leadership styles. The analysis was done in the context of Malaysia and abroad. The paper is written based on extensive secondary data analysis. After analyzing matters relating to instructional leadership, it can be concluded that instructional leadership is a form of leadership that every school leader needs to practice for excellence achievements in a school. With a lot of challenges nowadays, it needs to be addressed so that the direction of the school is on the right track and students' achievement can be enhanced.
\end{abstract}

Keywords: Concept Development; Definition; Instructional Leadership; Issues and Challenges in Executing Instructional Leadership; Literature Research; Model

\section{INTRODUCTION}

Education in Malaysia has been developing rapidly since this nation gained independence six decades ago. Malaysia government has always been concerned by taking initiatives to ensure our education system is comparable to those of developed countries while being up to date with the current changes that would suit global demand. The Prime Minister of Malaysia, Yang Amat Berhormat Dato' Seri Haji Mohd. Najib Bin Tun Haji Abdul Razak is also taking the same approach that was taken by the previous leaders by upholding Malaysian education towards advancement and competitiveness.

On the 11th of July 2009, The Prime Minister of Malaysia had announced six National Key Result Areas (NKRA) which is a Malaysian government initiative to fulfill the needs and demands of people after winning the 12th general election in 2008. The six areas are reducing crime rates,

Revised Manuscript Received on September 22, 2019.

Roslizam Bin Hassan, Faculty of Education, Universiti Teknologi Malaysia, zamhassan@yahoo.com

Jamilah Ahmad, Senior Lecturer, Faculty of Education, Universiti Teknologi Malaysia

Yusof Boon, Assoc. Prof., Senior Lecturer, Faculty of Education, Universiti Teknologi Malaysia fighting corruption, improving student outcomes, raising living standards of low-income households, improving rural basic infrastructure and improving urban public transport (Performance Management and Delivery Unit (PEMANDU), 2010).

Under the third NKRA or also known as Education NKRA, there are four sub-NKRA which explains in detail on the function of the particular NKRA. The four sub-NKRA are pre-school and early childcare, screening of literacy and numeracy skills (LINUS), identifying and rewarding High-Performing Schools and a new deal for school leaders who succeeded to improve school's excellence. Based on this sub-NKRA, it is obvious especially in the fourth NKRA that the aspect of principals' leadership is a vital element in upholding the education system in Malaysia. The fourth sub-NKRA also stated that school leaders are proven to help enhancing students' academic achievement (Performance Management and Delivery Unit (PEMANDU), 2010). In other word, school leaders do play a role in improving students' academic achievement both directly and indirectly (Jackson, Davis, Abeel, \& Bordonaro, 2000; Marzano, 2003). In addition, there is a research that shows that there is a strong correlation between students' academic achievement and the school leaders' leadership (Wilson, 2016).

Scholars, education practitioners and lawmakers have reached to a consensus stating that the school leaders' leadership is the main contributor in enhancing the performance and excellence of a school system (Fullan, 2007; Harris, 2013; Leithwood \& Jantzi, 2005). They also added that the leadership of the school leaders contributes to a better school performance while enhancing students' academic achievement (Day, Sammons, Hopkins, Leithwood, \& Kington, 2008; Hallinger \& Heck, 1996; Leithwood, Harris, \& Hopkins, 2008). The relationship between school leadership and students' academic achievement has also been stated specifically by Bogler (2005) and Waters, Marzano, and McNulty (2003) where they stated that the leadership style of a school leader can influence various elements in the school environment including the attitude of teachers and staffs, teaching and learning process and students' academic achievement.

Therefore, Ministry of Education Malaysia (MOE) has underlined three approaches to enhance students' success through the enhancement of school leaders' performance. The first approach is where the school leaders need to act as an instructional leader who is actively involved in teachers' development through planning, coordinating and evaluating teaching and learning (T\&L) process in school. Secondly, the school leaders act as the main agent of change in ensuring the vision and mission can be realized parallel to the school's goal for students' 
success. Finally, school leaders have to create a conducive school environment and supports $\mathrm{T} \& \mathrm{~L}$ process inside and outside classroom (Kementerian Pendidikan Malaysia, 2013).

In a preliminary report of the Malaysia Educational Blueprint 2013-2025, it is highlighted that students' success can be increased up to 20 percent if school leaders practice instructional leadership. This report also suggests that the responsibility as instructional leaders does not only lie on the school leaders only; the assistant principal, head of department and head of committee should also trained and be given trust to be instructional leaders (Kementerian Pendidikan Malaysia, 2012). Based on this brief description, it is proven that instructional leadership is a leadership model that is still relevant and trusted to bring schools under the ministry of education to keep moving forward in empowering students' academic achievement and personality to produce quality human capital.

\section{DEFINITION OF INSTRUCTIONAL LEADERSHIP}

The word "instructional" is originated from the word "instruction" which means teaching. In the context of school and daily usage, the term "teaching" is more commonly used than the term "instructional" because of its exclusivity of meaning in the English language. Hence, the term "instructional leadership" is more commonly used than "teaching leadership" although both carry the same meaning, which is any action or activity executed by the school leader to enhance T\&L process (James \& Balasandran, 2013). Various definition of instructional leadership has been stated by many researchers and scholars in educational leadership. One of them is a type of leadership that affect school's development (Kis \& Konan, 2014) and a leadership that uses knowledge in solving academic problems and educating teachers to know their roles to realize the school goal (Krug, 1992).

Drake and Roe (2002) defines instructional leadership as any effort towards encouraging and supporting parties that are involved in the T\&L process to achieve school goal and developing a strong school social system. According to Hallinger and Murphy (1985a), instructional leadership is any activity executed by the school administration in hope to improve the success of $\mathrm{T} \& \mathrm{~L}$ process and school development. Instructional leadership is also referred as a chain of action taken by school leaders aiming to enhance students' learning development (De Bevoise, 1984) and students' learning condition in school (Greenfield, 1987).

Sisman (2016) refers to instructional leadership as the power and behaviour used by school leaders, teachers and school supervisor to affect individuals and situation in school. The most important aspect that differentiates instructional leadership and other educational leadership is that it focuses more on the T\&L process in school. He added that there are five behaviors of instructional leadership that should be practiced by school leaders which are (1) identifying and sharing school objective, (2) administrating curriculum and instructional process, (3) evaluating instructional process and students' academic achievement,
(4) supporting teachers while enhancing their quality and (5) creating positive learning environment and school climate.

On the other hand, Hallinger $(2011,2000,1987)$ stated that instructional leadership is an effort executed by school leaders to improve $\mathrm{T} \& \mathrm{~L}$ process that involves teachers, parents, students and a combination of planning, organization, facilities and school culture. School leaders need to ensure each individual in school cooperates and helps one another in executing the best educational programme. Based on this definition, three main dimensions of instructional leadership are created which are defining goal, organizing instructional programme and encouraging school climate that will be the main basis in this concept paper.

\section{DEVELOPING THE CONCEPT OF INSTRUCTIONAL LEADERSHIP}

Instructional leadership has gained the attention of many educational researchers and lawmakers since more than three decades ago and it started with a research on effective school (Bossert et al., 1982; Edmonds, 1979; Hallinger \& Murphy, 1985a, 1987; Smith \& Piele, 2006; Southworth, 2002). Instructional leadership starts in between late 1970's and early 1980s with the emergence of researches that compare effective primary school and non-effective primary school for poor children in the northern parts of America.

Before the existence of researches related to school leaders, school-related researches only focused on socioeconomic status, social background and race as the factors of a student's success. But after the emergence of researches on effective school, the focus was shifted to identifying characteristics and practices of the school leaders in improving students' academic achievement (Brookover \& Lezotte, 1979; Edmonds, 1979). Around 1980's, researches on school leaders practicing instructional leadership grew vigorously (Bossert et al., 1982; Dwyer, 1985; Hallinger \& Murphy, 1985b; Leithwood \& Montgomery, 1982). According to several education scholars, there are only two leadership models that mostly dominated school or other educational institution which are instructional and transformational leadership (Hallinger \& Heck, 1998; Leithwood \& Jantzi, 2000; Robinson et al., 2008). This proves that even if the age of leadership has passed three decades, it is still relevant to be practiced in school until today.

The early development of instructional leadership among school leaders in Malaysia started in early 1980's. The Committee to Study Education Standard in Schools reported that school leaders should be responsible towards students' academic achievement in school and suggested a shift on the main task of principals or headmasters from school administration to instructional leaders (Kementerian Pendidikan Malaysia, 1982). Starting from this report, instructional leadership began to be implemented in schools around Malaysia.

Until today, even this leadership has reached more than 30 years of age, it is still used and relevant in developing schools and improving students' academic achievement. Ministry of Education Malaysia and all State Education Department make instructional leadership

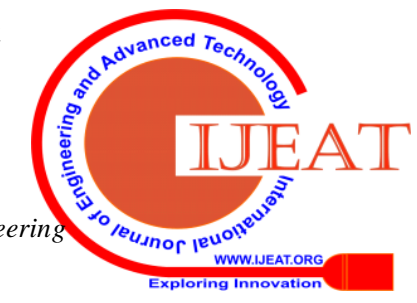


as the key performance indicator (KPI) that needs to be achieved successfully. Some education department uses the term "empowering instructional leadership" since instructional leadership has been long introduced and spread in schools, but there are a number of school leaders who are still lacking in practicing it. School leaders were found to be more focused on administrative business and school management. With this empowerment approach, it is hoped that school teachers could practice it again and make is a school culture for students' excellence.

\section{INSTRUCTIONAL LEADERSHIP MODELS}

Various instructional leadership models have been developed by education scholars to define dimensions and functions or roles that can be practiced by school leaders in executing their responsibilities as an instructional leader. For this subtopic, the researcher presents three main instructional leadership models that are frequently discussed in academic researches which are Murphy's Instructional Leadership Model (1990), Weber's Instructional Leadership Model (1996) and Hallinger's Instructional Leadership Model (2011).

\section{A. Murphy's Instructional Leadership Model (1990)}

Murphy (1990) has created a framework on instructional leadership based on his researches on school efficacy and improvement, staff development and organization changes. Based on his research, he explained that there are four dimensions and 16 functions that need to be practiced by an instructional leader. Figure 1 shows Instructional Leadership Model developed by Murphy (1990). Based on the figure, the first dimension of instructional leadership is creating mission and goal in which these will act as the foundation in developing shared vision and goal, and ensuring all activities and efforts executed by school are heading towards that vision and goal. Murphy had divided this dimension into two main functions which are firstly, to construct school goal and secondly, to spread school goal. According to Murphy (1990), students' academic achievement becomes the basis or foundation of school goal construction. The constructed school goal needs to be shared frequently whether formally or informally to students, parents and teachers to make sure all activities that are carried out in school are heading towards the goal that was constructed together.

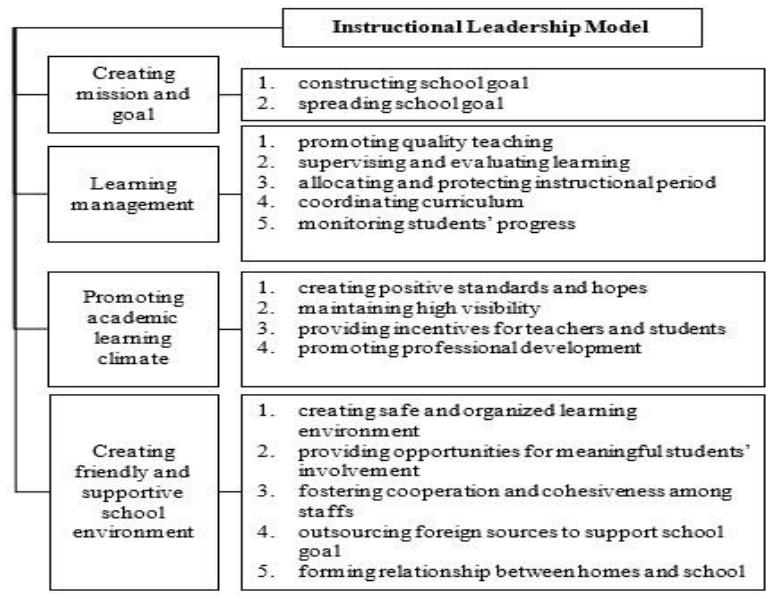

Fig 1 Murphy’s Instructional Leadership Model (1990)
The second dimension is learning management that highlights on the role of school leaders' management in administrating $\mathrm{T} \& \mathrm{~L}$ process in school. This dimension involves five functions in particular which are (1) promoting quality education, (2) supervising and evaluating learning, (3) allocating and protecting instructional period, (4) coordinating curriculum and (5) monitoring students' progress. Instructional leader may encourage quality teaching through discussions with teachers in curriculum meetings, teachers' instructional evaluation, visits to classroom like learning walk, discussion during observation session and many more. In addition, school leaders should protect instructional period properly through a suitable procedure. Instructional leaders and teachers should discuss together on coordinating school curriculum through goal and objectives adjustments to fulfill current demand of the national curriculum. Moreover, instructional leaders should also always monitor students' progress by using evaluation data so that the goal and teachers' approaches during the T\&L process can be modified according to students' needs.

The third dimension is promoting academic learning climate which refers to school leaders' action that could influence norms, beliefs and attitudes of teachers, students and parents of a school (James \& Balasandran, 2013). This dimension encompasses four functions which include (1) creating positive standards and hope, (2) maintaining high visibility, (3) providing incentives for teachers and students, and (4) promoting professional development. According to Murphy (1990), principals or headmasters can instill conducive school learning climate development through T\&L process by setting positive standards and hopes, maintaining high visibility, providing incentives for teachers and promoting professional development.

The fourth dimension which is to create friendly and supportive school environment explains the instructional leaders' role to create an organization structure and enhancing processes that would support T\&L executions (James \& Balasandran, 2013). Principals and headmasters who succeeded to practice this dimension are able to create safe and organized learning environment (first function), providing opportunities for meaningful students' involvements (second function), instilling cooperation and cohesiveness among staffs (third function), outsourcing foreign sources to support school goal (fourth function) and forming relationship between homes and school (fifth function).

However, this leadership model has its flaws. According to Alig-Mielcarek (2003), Murphy's Instructional Leadership Model has flaws as compared to the Instructional Leadership Model constructed by Hallinger (2011). This Instructional Leadership Model is not tested empirically in schools although this model is created based on literature research and deep observation by Murphy towards school leadership.

\section{B. Weber's Instructional Leadership Model (1996)}

Weber (1996), an expert of collaborative concept in management field had identified five dimensions in instructional leadership framework. The five dimensions are as shown in 
Figure 2. The first dimension is defining school mission. Weber explained that defining school mission is a dynamic process that demands cooperation and energy mobilization of all parties including leaders, staffs, teachers, students and parents to create a clear, honest and achievable mission. The second dimension is managing curriculum and learning. According to Weber, the effort of managing curriculum and learning should be in accordance to the school mission. Instructional leaders should have the skills to guide teachers in the aspect of $\mathrm{T} \& \mathrm{~L}$ process whether inside or outside classroom so that students could get the best learning experience. School leaders should also assist teachers to use best practices to enable students to achieve academic achievement goal that has been set by the school.

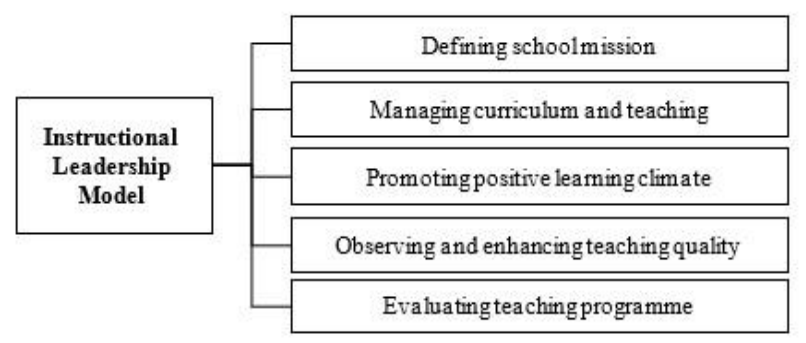

Fig 2 Weber's Instructional Leadership Model (1996)

The third dimension is promoting positive learning climate. To ensure that this dimension is achieved, school leaders should spread school goal widely, setting high achievement goal among students, creating an organized learning condition and improving teachers' commitment level in accomplishing their tasks. The fourth dimension is observing and improving teaching quality. Through this dimension, school leaders may execute observation of teachers' teaching activity as it is an interaction opportunity between teachers and school leaders. This observation is a professional development opportunity for both parties in sharing best practices, new knowledge and useful experience that are hard to find in reading materials. The fifth dimension is evaluating teaching programme. Instructional leaders are actuators and pioneers in contributing ideas for planning, designing, administrating and analyzing various kinds of evaluation in evaluating the effectiveness of a curriculum. Continuous evaluation of these curriculum programmes would enable teachers to fulfill students' learning needs effectively because improvement will be made based on the evaluation.

Nonetheless, this model has its flaws. According to Alig-Mielcarek (2003), although Weber's Instructional Leadership Model (1996) is a combination of research findings on leadership sharing and teachers' ability to create schools that prioritize students' academic achievement, this model has not been empirically tested as compared to Hallinger's Instructional Leadership Model (2011) and it cannot be proven if there is a positive correlation between the five dimensions in this model and students' academic achievement.

\section{Hallinger's Instructional Leadership Model (2011)}

Hallinger (2011) underlined three dimensions and 10 instructional leadership functions in evaluating school leaders' instructional leadership level. The three dimensions are defining school goal, managing instructional programme and promoting school climate. These three dimensions comprises 10 functions that explain in detail the roles and tasks of instructional leaders in school. This leadership model is as shown in Figure 3.

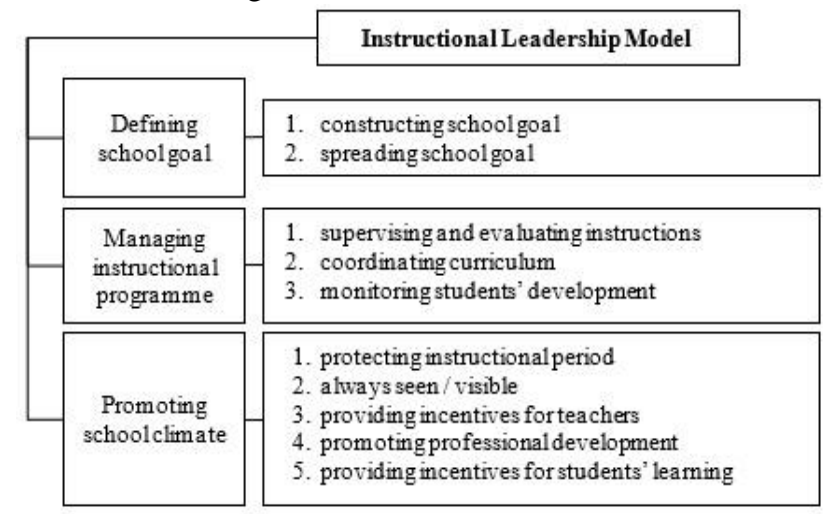

Fig 3 Hallinger's Instructional Leadership Model (2011)

The first dimension, defining school goal, comprises two functions which are (1) constructing school goal and (2) spreading school goal. The second dimension is managing instructional programme. This dimension has three functions which are (1) supervising and evaluating instructions, (2) coordinating curriculum and (3) monitoring students' development. The third dimension is promoting school climate which comprises five functions which are (1) protecting instructional period, (2) always seen or visible, (3) providing incentives for teachers, (4) promoting professional development and (5) providing incentives for students' learning. Further explanation regarding this dimension and its functions will be stated in the next topic.

Based on the three models that have been discussed, this concept paper has chosen the Instructional Leadership Model constructed by Hallinger (2011) as the best model because of several reasons. Firstly, it is because of the strength of the model. Hallinger's Instructional Leadership Model has been tested empirically in many researches regarding instructional leadership and has the widest usage in measuring a school leader's instructional leadership level (Alig-Mielcarek, 2003; Fulton, 2009; Gurley, Anast-May, O’Neal, \& Dozier, 2016b; Pettiegrew, 2013). Secondly, this model has created a research instrument that is strong, stable and has become one of the research instruments that has been widely used in the area of school leadership and management which is "Principal Instructional Management Rating Scale" (PIMRS) (Fulton, 2009; Gurley, Anast-May, O’Neal, \& Dozier, 2016a; Horton, 2013; Pettiegrew, 2013; Robinson et al., 2008).

This instrument has been used numerous times in studying school leaders' instructional leadership in the past 30 years and it is still relevant until today. Among the researches, local and international, that uses this instrument include Ahmad (2014); Andi (2006); Elangkumaran (2012); Fulton (2009); Gedik and Bellibas (2015); Gurley et al. (2016); Hallinger (2005, 2011); Hallinger et al. (2015); Hallinger, Dongyu, and Wang (2016); Hallinger and Murphy (1987); Jameela and Jainabee (2011); Latip (2007); Masitah and Khaidir (2015); Mohd and Aziz (2014); Mohd (2009); Nor and Haris (2013); Pettiegrew (2013); Rahimi

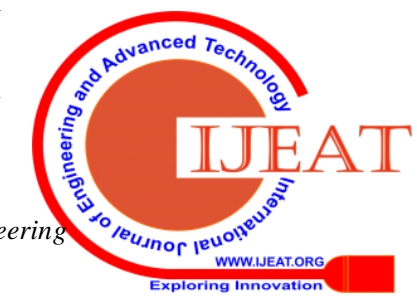


and Yusri (2015); Robinson et al. (2008); Shafinaz, Chua, Hussein, and Shahrin (2008) and Zakaria (2016). Hallinger (2011) has written a meta-analysis journal that studies the uses of PIMRS throughout these three decades which involves 130 philosophical doctorate and educational theses, and based on his study on all the theses, he suggested that PIMRS instrument is the strongest, most stable and has the highest reliability and validity in studying instructional leadership in school.

Other than the reasons stated above, the choice of this model is also made based on the strengths and weaknesses of the three instructional leadership models that had been discussed previously. Detailed description on the strengths and weaknesses of the three instructional leadership models are as shown in Table 1. Based on all the arguments, choosing Hallinger's Leadership Model as the best model to fulfill the needs and demands of instructional leadership is seen to be the most accurate.

Table 1 Strengths and Weaknesses of the Instructional Leadership Models

Strength:

1. This model is created based on deep researches on various literature studies regarding instructional leadership and observations on its executions in Murph schools. Based on the study, it produced the most dimensions and functions compared to the other models which comprises four dimensions and 16 functions (Alig-Mielcarek, 2003).

Weakness:

1. Not empirically tested and no questionnaire instrument was created from this model (Alig-Mielcarek, 2003).

Strength:

1. This model implemented research findings on leadership sharing and teachers' ability to create schools that highlight academic field and focus on the improvement of all students' academic

Weber achievement. (Alig-Mielcarek, 2003).

(1996) Weakness:

1. This model has not been empirically tested and it cannot be proven whether instructional leaders who practice this model can enhance students' academic achievement or vice versa (Alig-Mielcarek, 2003).

Strength:

1. This model is constructed based on a questionnaire and observations towards 10 schools to evaluate school leaders' instructional leadership behaviour. Hallinger had collected data on the "behaviours" from the research respondents who are the school leaders, school staff and their

Hallin district education supervisor (James \& ger Balasandran, 2013).

(2011) 2. This model has been tested in many empirical studies and has been used widely in measuring a school leader's instructional leadership level (Alig-Mielcarek, 2003; Fulton, 2009; Gurley et al., 2016b; Pettiegrew, 2013).

3. This model creates a strong and stabil instrument which has become one of the most widely used research instrument in the field of leadership and education management. The instrument is "Principal Instructional Management Rating Scale" (PIMRS) (Fulton, 2009; Gurley et al., 2016a; Horton, 2013; Pettiegrew, 2013;

Robinson et al., 2008).

\section{DIMENSIONS AND FUNCTIONS IN HALLINGER'S INSTRUCTIONAL LEADERSHIP MODEL (2011)}

The instructional leadership model constructed by Hallinger (2011) comprises three dimensions which are defining school goal, managing instructional programme and promoting school climate. Detailed explanation on these dimensions are as follows.

\section{A. Defining School Goal}

The dimension of defining school goal has two functions as stated previously which are constructing school goal and spreading it (Hallinger, 2011; 2000; Hallinger \& Murphy, 1987). Through this dimension, the main role of school leaders is to set school goal. School leaders should know what to be achieved by the school and the direction they are heading to. A school which have no direction in educational process has no criteria to measure whether they have succeeded in executing the process or not (Krug, 1992). This dimension focuses on leaders' role in carrying out their responsibilities together with the people under them to ensure the school has clear and measurable goal and has a timeline for students' academic progress. Leaders are also responsible to clarify the constructed goal so that all parties are aware of it and this could ease supports and aids from the school community to ensure the goal is achieved (Hallinger, 2005).

Based on this model, the process of constructing goal is seen as less critical than its outcome. The goal may be constructed by the school leader, or collaboratively with other school staffs. However, it is appropriate to question if the school has a clear goal that would enable everyone in the school community to support and cooperate towards the goal. This is because sometimes, there is a blurry, confusing and even conflicting goal that would lead to difficulty in getting the desired outcome based on the goal that has been set (Hallinger, 2011; 2000; Hallinger \& Murphy, 1987).

The role of instructional leaders in defining school goal can be seen more clearly in a research done by Hallinger and Murphy (1986) on an effective primary school in California. From the interview with the school leader and teachers, six characteristics that a school leader should have in defining school goal had been summarized. Firstly, the school's vision and mission should be clear and understandable for everyone in the school community. The goal should be written or displayed around school to ensure that everyone can see it easily and making them aware and concerned on the school's direction. Secondly, the school goal should focus on academic development based on the school needs and suitability. Thirdly, the school goal should be all teachers' priority in doing their tasks. Fourth, the goal should be accepted and verified by all teachers in the school. Fifth, the goal should be excellently articulated by the leader and finally, the goal should be

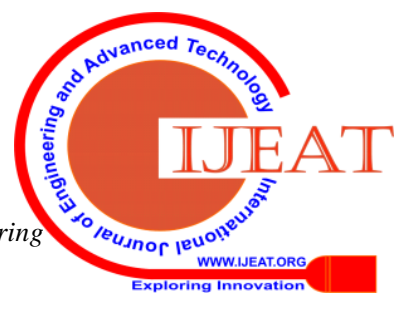


supported by everyone in the school community. Hence, the school leader himself should portray the best example in realizing the goal.

\section{B. Managing Instructional Programme}

The second dimension is managing instructional programme. This dimension focuses on controlling and coordinating things related to curriculum and teaching. According to James and Balasandran (2013), this dimension is the biggest task and challenge that school leaders have to face because the curriculum and teaching is the core function of a school. Failure in accomplishing the task of managing instructional programme efficiently and effectively will cause failure in getting the desired outcome on students' academic achievement. There are three functions of this dimension which are firstly, supervising and evaluating instructions, secondly, coordinating curriculum and finally, monitoring students' progress (Hallinger, 2011; 2000; Hallinger \& Murphy, 1987).

According to Hallinger $(2011,2000)$, the first function of this dimension, which is supervising and evaluating instruction, refers to the school leaders' initiative to ensure that the school goal can be fully translated and practiced in the process of T\&L in the classroom. For the second function which is coordinating curriculum, school leaders should align teaching objectives with learning activities in classroom, assessment process and coordinating instructional programme. School leaders should also assign several individuals who would be responsible in coordinating curriculum, analyzing students' examination result and making decisions to choose curriculum materials as teaching aids. Furthermore, the third function, which is monitoring students' progress, school leaders should hold a continuous discussion with teachers regarding students' academic development and achievement, giving specific opinions and initiate ways of improvements for the $\mathrm{T} \& \mathrm{~L}$ process to enhance students' achievement.

Based on the explanation above, the second dimension needs active involvement of school leaders in boosting, supervising and monitoring $\mathrm{T} \& \mathrm{~L}$ process in school. Therefore, school leaders should have the knowledge, experience and expertise in $\mathrm{T} \& \mathrm{~L}$ and at the same time, committed to all school enhancement programmes. Through this dimension, school leaders will be the expert in all instructional programmes in school (Bossert et al., 1982; Cuban, 1983; Dwyer, 1985; Edmonds, 1979; Marshall, 2003).

A research by Hallinger and Murphy (1986) towards an effective school in California found that the school teachers observed several behaviours of the headmaster that is said to be monitoring students' development. They observed that the headmaster was able to know the literacy and advancement level of all 650 students in the school. Although this behaviour is not a requirement in instructional leadership, this reflects the headmaster's effort in monitoring students' progress other than managing teaching programmes in the school.

\section{Promoting School Climate}

The third dimension is promoting school climate. There are five functions in this dimension which are (1) protecting instructional period, (2) always seen or visible, (3) providing incentives for teachers, (4) promoting professional development and (5) providing incentives for students' learning (Hallinger, 2011; 2000). Hallinger $(2011$, 2000) had modified leadership model and concept that was constructed with his partner which is Hallinger and Murphy's Instructional Leadership Model (1987, 1985). Nonetheless, after doing several validity and reliability tests, he dropped one of the six functions in the third dimension which is strengthening academic standard. Thus, for this latest leadership model, the dimension of promoting school climate only has five functions as stated above and it remains the same until today.

According to Hallinger $(2011,2000)$, the third dimension refers to norms and attitudes of teachers and students that affect learning process in school. School leaders should create a school climate, directly or indirectly, through their capability in maintaining visibility to ease communication, discussion and to provide platform to approach teachers and students, creating reward system to boost the school community's productivity towards enhancing students' academic achievement, creating clear standards comprising the school's expectation for the students, protecting teaching period and taking part in development programmes for the school community that are aligned with the school mission.

This dimension has the widest scope and purpose as compared to the two previous dimensions. This proves the view that an effective school will usually create an academic press through the development of high standards and expectations for students and teachers to excel in academic and learning (Bossert et al., 1982; Purkey \& Smith, 1983). In the aspect of teaching, an effective school creates a "continuous development" culture, where every success in practicing a good deed that contributes to school development shall be rewarded (Barth, 1990; Glasman, 1984; Hallinger \& Murphy, 1986; Heck, Larsen, \& Marcoulides, 1990; Leithwood \& Montgomery, 1982; Mortimore, 1993; Purkey \& Smith, 1983). The head master should also portray good examples in morals and practices that can create continuous development climate in the aspect of $\mathrm{T} \& \mathrm{~L}$ (Dwyer, 1985).

\section{ISSUES IN PRACTICING INSTRUCTIONAL LEADERSHIP}

There are many researches that shows the existence of flaws in school leaders and challenges in practicing instructional leadership. This subtopic will explain in detail issues, weaknesses and challenges faced by school leaders in practicing instructional leadership. According to Heck and Hallinger (2010), there are many issues and weaknesses in practicing instructional leadership despite this leadership model has been a reference for school leadership researchers. The first issue is that this leadership model is hierarchical, which comprises top-down relationship of a school leader and teachers. Based on the

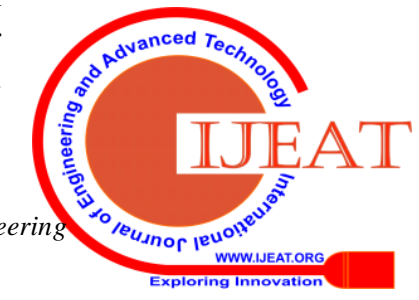


practice of instructional leadership, school leaders will act as curriculum expert and supervisor of teaching process and curriculum. The top-down relationship between the expert or supervisor and teachers will create discomfort among teachers especially when the school leaders are intending to monitor the $\mathrm{T} \& \mathrm{~L}$ process or while checking their work outcome (Goddard, 2003).

The second issue is difficulty of school leaders to be experts in all fields of teaching or curriculum (Hallinger, 2003). Hence, in this situation, school leaders should instill learning culture among the school community especially teachers so that all kinds of expertise in every teacher can be fully utilized by the school for the students' academic improvement. The third issue that other than being instructional leaders in school, they also have to attend to other tasks such as administrative business and this causes them to not have enough time to carry out their duty as instructional leaders (Cuban, 1983; Hallinger, 2003; Stronge, 1993). This situation is also supported by Goodwin, Cunningham, and Childress (2003) who stated that local social and community authorities often forces school leaders with many current demands on education. This causes imbalance in the issue of school management and leadership other than increasing confusion and complexity in carrying out the duties, where this could lead to decrease in moral and enthusiasm of the school leaders. Moreover, the community's high expectation towards the school leaders is adding more responsibilities to the leaders towards various demands of the society and this causes failure in accomplishing tasks and duties as instructional leaders (Catano \& Stronge, 2007; Cuban, 1983).

School leaders' capability in practicing instructional leadership in enhancing students' academic achievement may also be declined. There are empirical evidences which stated that school leaders still failed to enhance students' learning quality even after practicing instructional leadership (Cuban, 1983; Hallinger, 2008). In another research, Leithwood (2012) found that students perceived that school leaders' role in improving their learning quality is low, which is between 12 to 25 percent, while the influence of outside environment and family factor contributes up to 50 percent of influence towards students' academic achievement (Leithwood, Patten, \& Jantzi, 2010).

Since several decades ago, there was a pressure that demands school leaders to reduce management tasks and focus more on the tasks as instructional leaders. For school leaders who have left teaching for a long time (due to involvement in school management and administration), being involved again in the teaching and instructional field with the goal of enhancing teachers' instructional performance is surely a big challenge for them (Hallinger, 2003; Stronge, 1993). Hallinger (2011) also found that school leaders are always pressured to carry out responsibilities as instructional leaders fully because it was convinced to enhance students' academic achievement, yet the leaders are also expected fulfill other tasks such as school management and administrative business. Busyness in handling various management and administrative tasks is limiting school leaders to carry out their responsibilities as instructional leaders, especially in supervision tasks and monitoring teachers' T\&L sessions. In the end, the supervision and monitoring of $\mathrm{T} \& \mathrm{~L}$ tasks are shifted to assistant principals and heads of department (Hallinger, 2005).

Goodwin et al. (2003) has presented bureaucracy problem, social community pressure, negotiations between many parties and educational reforms that constantly happen had caused the headmasters' role as instructional leaders to be eradicated bit by bit to the extent that they perceived themselves as educators and not leaders. Their role as school leaders have also undergone big changes since the past decades and this only increases their tasks' complexity to lead. This big change demands school leaders to spend more time in executing their tasks in leading and administrating their school as compared to the previous leaders (Goodwin et al., 2003; Lashway, 2003). As a result, today's school leaders have to fulfill their responsibilities in three conditions which are full of pressure (increasing as time passes), in need of too rigid reports and insufficient time (Tirozzi, 2001; Volante, Cherubini, \& Drake, 2008).

In the context of education in Malaysia, instructional leadership practices here also have their issues and challenges. Findings from Teachers' Teaching and Movement Monitoring Data Report by Pahang State Education Department in the year 2009 showed some of the causes of the planned instructional programme often not parallel to the school goal were the lack of efficacy in school leaders' role in guidance and failure in sharing and articulating school information with the teachers. This problem had given negative effect towards the quality of teachers' T\&L process and students' academic achievement (Jabatan Pendidikan Negeri Pahang, 2009).

Kementerian Pendidikan Malaysia (2007) through the Inspectorate of Schools Report for Year 2006 found that the main cause for the problems in teachers' $\mathrm{T} \& \mathrm{~L}$ process is when school leaders fail to portray effective instructional leadership. Various occurring problems were caused by weak practice of instructional leadership. Some of them were teachers teaching by following the syllabus too rigidly, being exam oriented without digesting students' demands and also not fulfilling student-centered teaching concept. Furthermore, this report also stated that there were teachers who taught without set induction, practiced teacher-centered teaching, used non-systematic strategic planning, had average level of teaching quality and there were less monitoring from the school administration other than loose assessment system.

The issue regarding instructional leadership is also mentioned in the Annual Report 2014: Malaysia Education Blueprint 2013-2025. The report exposed low-performing District Education Offices and the identified factors that contribute to this issue are flaws in practicing instructional leadership among the districts' school leaders and decline in T\&L quality in classroom (Kementerian Pendidikan Malaysia, 2015). Both factors are perceived as related to each other. It started with the flaws from school leaders, affecting teachers under the leadership. This report also identified five key areas that have significant 
impact in enhancing students' academic achievement in school. The five areas are students' attendance, students' discipline, teachers' attendance, teaching quality and school leadership. All these areas should exist within a school as it is vital for the improvement of students' academic achievement and school effectiveness.

After researching the issues and challenges regarding instructional leadership locally and internationally with the reports from Ministry of Education Malaysia (MoE), Johor State Education Department has highlighted the issue on instructional leadership. In a Johor State Curriculum Committee Meeting Number 3/2011, the Director of Johor State Education Department stressed that in order to overcome the issue of students losing focus during the T\&L process in classroom, one of the curriculum tasks that required attention is the practices of instructional leadership (Jabatan Pendidikan Negeri Johor, 2011). Hence, School Management Sector of Johor State Education Department and District Education Offices were given full responsibility to ensure instructional leadership practice can be nourished in all schools in Johor. The meeting also received feedback from a District Education Office, stating that the issues regarding $T \& \mathrm{~L}$ process in the classroom is a vital issue and it cannot be taken lightly. This issue had been discussed in a Professional Assembly in a secondary school on the 31st of March 2011 and 12th of December 2011, where the principals and headmasters were responsible to reevaluate curriculum management in their schools and prioritize monitoring at school level so that teachers' teaching will be more effective and interesting. Principals and headmasters were also reminded on the principles and practices of instructional leadership so that curriculum management in Johor state level is on the right track.

Moreover, in Curriculum Committee Meeting Number 3/2012, Johor State Education Department, the Director of Johor State Education Department reminded on fundamental responsibility of all officers in Johor State Education Department, District Education Offices, principals and headmasters on the needs to master the practices of instructional leadership (Jabatan Pendidikan Negeri Johor, 2012). To ensure that this would be executed, Academic Management Sector of Johor State Education Department and all District Education Offices were assigned to guide principals and headmasters, whether novice or experienced, on instructional leadership. The Director of State Education Department also highlighted that the practice of protecting instructional period should be fully executed in all schools and becomes the fundamental in enhancing instructional leadership process among school leaders in Johor. Recently, Quality Guarantee Sector of Johor State Education Department under Tuan Haji Kamaruddin bin Abu has underlined several steps for consultation and school leaders' management, and some of the initiatives include maintaining and increasing instructional leadership quality among school leaders in Johor.

Melaka State Education Department has also taken the same initiative as Johor State Education Department. Melaka State Education Department Strategic Planning 2015-2019 responded on MoE's plan to empower instructional leadership through the second main strategy which is empowering teachers and school leaders' competency (Jabatan Pendidikan Negeri Melaka, 2014). From this second main strategy, Melaka State Education Department will focus on the practices of instructional leadership among school leaders while expecting them to be excellent instructional leaders that act as agent of change and succeed in achieving higher expected goal. School leaders should always be open to new work culture, involving local community in improving school performance and maximize students' success with every ringgit spent (Jabatan Pendidikan Negeri Melaka, 2014). In Negeri Sembilan, the importance of instructional leadership is also stated in Negeri Sembilan State Education Department Strategic Planning (2013-2015) through the second strategic core which is high international quality standard. Negeri Sembilan State Education Department put practicing instructional leadership as the fifth strategy to improve school management and leadership. Instructional leadership is also needed to enhance education quality at state level with the purpose of producing human capital that masters 21st century skills and knowledge (Jabatan Pendidikan Negeri Sembilan, 2012).

Other than these issues and challenges in practicing instructional leadership in other countries or in Malaysia, one scenario of the researches on instructional leadership was found, in which the research findings are focusing more on the context of western countries education culture. A challenge emerged in the field of instructional leadership to develop more researches on this leadership model in the context of Asian countries to explore how school leaders in different education context practice instructional leadership (Hallinger \& Bryant, 2014). Hence, this study challenges the researched by researching on instructional leadership practices in Malaysia, a country where there were not much of empirical researches on school leadership (Bajunid, 1996).

Based on the researches and educational reports above, it is concluded that instructional leadership is one of the most trusted leadership in bringing school towards a better direction by acting as the agent to improve the quality of teachers' T\&L and students' academic achievement although this leadership model has passed 30 years of age. Nevertheless, behind the success, there lie several issues and challenges in practicing it. Some of the challenges are incapability of school leaders to be experts in all teaching field, school leaders having limitation to carry all responsibilities because of various challenging work demand and the existence of discomfort or anxiousness among teachers in a hierarchical relationship between school leaders and teachers while practicing instructional leadership.

\section{CONCLUSION}

Instructional leadership is a leadership model that needs to be practiced by all school leaders to drive the schools towards excellence. Ministry of Education Malaysia highlighted that school leaders should act as instructional leaders who are actively involved in teachers' development by planning, coordinating and evaluating the process of teaching and learning $(\mathrm{T} \& \mathrm{~L})$ in school. Although various challenges and issues exist in practicing this model of leadership, they need to be handled properly so that quality $\mathrm{T} \& \mathrm{~L}$ process can be

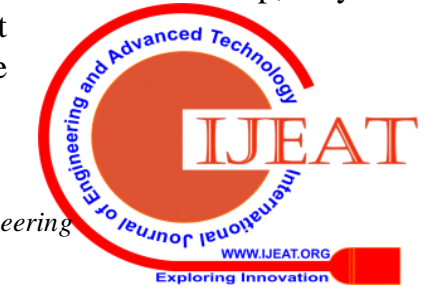


carried out in classroom, thus giving positive impact towards students' academic achievement.

\section{REFERENCES}

[1] Ahmad, F. A. (2014). Kepimpinan instruksional dalam peningkatan pengajaran dan pembelajaran yang berkesan dalam kalangan pensyarah. Universiti Tun Hussein Onn Malaysia. leadership, academic press, and student achievement. The Ohio State University. http://doi.org/10.1024/0301-1526.32.1.54

[3] Andi, A. M. N. (2006). Kepimpinan pengajaran dan efikasi kendiri pengetua sekolah menengah dan hubungannya dengan pencapaian akademik sekolah. Universiti Teknologi Malaysia.

[4] Bajunid, I. A. (1996). Preliminary explorations of indigenous perspectives of educational management: The evolving Malaysian experience. Journal of Education Administration, 34(5), 50-73.

[5] Barth, R. S. (1990). Improving schools from within: Teachers, parents, and principals can make the difference. San Francisco: Jossey-Bass.

[6] Bogler, R. (2005). Satisfaction of Jewish and Arab Teachers in Israel. Journal of Social Psychology, 145(1), 19-33. http://doi.org/10.3200/SOCP.145.1.19-34

[7] Bossert, S. T., Dwyer, D. C., Rowan, B., \& Lee, G. V. (1982). The instructional management role of the principal. Educational Administration Quarterly, 18(3), 34-64.

[8] Brookover, W. B., \& Lezotte, L. W. (1979). Changes in school characteristics coincident with changes in student achievement (1st ed.). East Lansing, MI.: Michigan State University.

[9] Catano, N., \& Stronge, J. H. (2007). What do we expect of school principals? Congruence between principal evaluation and performance standards. International Journal of Leadership in Education, 10(4) 379-399. http://doi.org/10.1080/13603120701381782

[10] Cuban, L. (1983). Transforming the frog into the prince: Effective school research, policy and practice at the district level. Washington, DC.

[11] Day, C., Sammons, P., Hopkins, D., Leithwood, K., \& Kington, A. (2008). Research into the impact of school leadership on pupil outcomes: Policy and research contexts. School Leadership and Management, $28(1)$

$5-25$. http://doi.org/10.1080/13632430701800045

[12] De Bevoise, W. (1984). Synthesis of research on the principal as instructional leader. Educational Leadership, 41(5), 14-20.

[13] Drake, T. L., \& Roe, W. H. (2002). The principalship (6th ed.). New York: Pearson.

[14] Dwyer, D. C. (1985). Understanding the principal's contribution to instruction. Peabody Journal of Education, 63(1), 3-18.

[15] Edmonds, R. (1979). Effective Schools for the urban poor Educational Leadership, 37(October), 15-24.

[16] Elangkumaran, D. (2012). Hubungan antara kepimpinan pengajaran guru besar dengan komitmen kerja Dan kepuasan kerja guru sekolah rendah di zon Tanjung Karang. Kepemimpinan Untuk Pembelajaran (Leadership For Learning).

[17] Fullan, M. (2007). The new meaning of educational change. Change (4th. Ed.). New York and London: Teacher College Press. http://doi.org/10.1007/s10833-006-9003-9

[18] Fulton, T. T. (2009). High school principal instructional leadership behavior in high and low need and high and low achievement schools. Downling College.

[19] Gedik, S., \& Bellibas, M. S. (2015). Examining schools' distributed instructional leadership capacity: Comparison of elementary and secondary schools. Journal of Education and Training Studies, 3(6), 101-110. http://doi.org/10.11114/jets.v3i6.1056

[20] Glasman, N. S. (1984). Student achievement and the school principal. Educational Evaluation and Policy Analysis, 6(3), 283-296.

[21] Goddard, J. T. (2003). Leadership in the (post) modern era. In N. Bennet \& L. Anderson (Eds.), Rethinking Educational Leadership (pp. 11-26). London: SAGE Publication.

[22] Goodwin, R. H., Cunningham, M. L., \& Childress, R. (2003). The changing role of the secondary principal. NASSP Bulletin, 87(634), 26-42.

[23] Greenfield, W. (1987). Instructional leadership: Concepts, issues and controversies. Newton MA: Allyn and Bacon.

[24] Gurley, D. K., Anast-May, L., O’Neal, M., \& Dozier, R. (2016a) Principal Instructional Leadership Behaviors: Teacher vs Self-Perceptions. International Journal of Educational Leadership Preparation, 11(1), 140-155.
[2] Alig-Mielcarek, J. M. (2003). A model of school success: Instructional

[25] Gurley, D. K., Anast-May, L., O’Neal, M., \& Dozier, R. (2016b) Principal instructional leadership behaviours: Teacher vs. self-perceptions. In G. Babo, C. Wells, \& N. R. Templeton (Eds.), International Journal of Educational Leadership Preparation (Vol. 11, pp. 140-155). Virginia, USA: NCPEA Publication.

[26] Hallinger, P. (2000). A review of two decades of research on the principalship using the Principal Instructional Management Rating Scale. In Paper presented at the annual meeting of the American Educational Research Association, Seattle, Washington.

[27] Hallinger, P. (2003). Leading educational change: Reflections on the practice of instructional and transformational leadership. Cambridge Journal of $\quad 33(3)$, 329-352. http://doi.org/10.1080/0305764032000122005

[28] Hallinger, P. (2005). Leadership and policy in schools instructional leadership and the school principal: A passing fancy that refuses to fade away instructional leadership and the school principal : A passing fancy that refuses to fade away. Leadership and Policy in Schools, 4(3), 221-239. http://doi.org/10.1080/15700760500244793

[29] Hallinger, P. (2008). Methodologies for studying school leadership: A review of 25 years of research using the principal instructioal manadement rating scale. In Paper presented at the annual meeting of the American Educational Research Association, New York. (p. 48).

[30] Hallinger, P. (2011). A review of three decades of doctoral studies using the Principal Instructional Management Rating Scale: A lens on methodological progress in educational leadership. Educational Administration Quarterly, 47(2), 271-306 http://doi.org/10.1177/0013161X10383412

[31] Hallinger, P., \& Bryant, D. (2014). Mapping the terrain of educational leadership and management in East Asia. Journal of Education Administration, 51(5), http://doi.org/10.1108/JEA-05-2012-0066

618-637

[32] Hallinger, P., Dongyu, L., \& Wang, W.-C. (2016). Gender Differences in Instructional Leadership: A Meta-Analytic Review of Studies Using the Principal Instructional Management Rating Scale. Educational Administration Quarterly, 52(4), 567-601. http://doi.org/10.1177/0013161X16638430

[33] Hallinger, P., \& Heck, R. H. (1996). Reassessing the principal's role in school effectiveness: A review of empirical research, 1980-1995. Educational Administration Quarterly, 32(1), 5-44. Retrieved from http://eaq.sagepub.com/content/32/1/5.short

[34] Hallinger, P., \& Heck, R. H. (1998). Exploring the principal's contribution to school effectiveness: 1980-1995. School Effectiveness and School Improvement, 9(2), 157-191.

[35] Hallinger, P., \& Murphy, J. (1985a). What's effective for whom? School context and student achievement. Planning and Changing, 16(3), 152-160

[36] Hallinger, P., \& Murphy, J. (1986). The social context of effective schools. American Journal of Education, 94(3), 328-355.

[37] Hallinger, P., \& Murphy, J. F. (1985b). Assessing the instructional management behavior of Principals. The Elementary School Journal, 86(2), 217-247.

[38] Hallinger, P., \& Murphy, J. F. (1987). Assessing and developing principal instructional leadership. Educational Leadership, 9, 54-61. Retrieved from http://www.ascd.org/ASCD/pdf/journals/ed_lead/el_198709_hallinge r.pdf

[39] Hallinger, P., Wang, W. C., Chen, C. W., \& Li, D. (2015). Assessing instructional leadership with the principal instructional management rating scale. New York: Springer International Publishing Switzerland. http://doi.org/10.1007/978-3-319-15533-3

[40] Harris, A. (2013). Distributed leadership matters. Thousands Oaks, CA: Corwin Press.

[41] Heck, R. H., \& Hallinger, P. (2010). Testing a longitudinal model of distributed leadership effects on school improvement. The Leadership Quarterly, 21(5), 867-885. http://doi.org/10.1016/j.leaqua.2010.07.013

[42] Heck, R. H., Larsen, T. J., \& Marcoulides, G. A. (1990). Instructional leadership and school achievement: Validation of a causal model. Educational Administration Quarterly, 26(2), 94-125. http://doi.org/10.1177/07399863870092005

[43] Horton, T. (2013). The relationship between teachers'sense of efficacy and perceptions of principal instructional leadership behaviors in high poverty schools. The University of Texas.

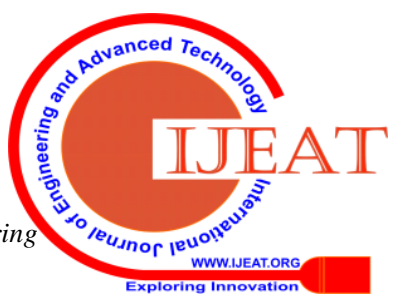


[44] Jabatan Pendidikan Negeri Johor. (2011). Mesyuarat Jawatankuasa Kurikulum Negeri Johor Bilangan 03/2011. Johor.

[45] Jabatan Pendidikan Negeri Johor. (2012). Minit Mesyuarat Jawatankuasa Kurikulum Bilangan 3/2012. Johor.

[46] Jabatan Pendidikan Negeri Melaka. (2014). Perancangan Strategik Jabatan Pendidikan Melaka 2015-2019. Melaka.

[47] Jabatan Pendidikan Negeri Pahang. (2009). Laporan data pemantauan pengajaran dan pembelajaran dan pergerakan guru. Pahang.

[48] Jabatan Pendidikan Negeri Sembilan. (2012). Pelan Strategik Jabatan Pendidikan Negeri Sembilan 2013-2015. Negeri Sembilan.

[49] Jackson, A. W., Davis, G. A., Abeel, M., \& Bordonaro, A. (2000). Turning points 2000: Educating adolescents in the 21st century (1st ed.). New York \& Westerville: Teachers College Press.

[50] Jameela, B. A., \& Jainabee, M. K. (2011). Amalan kepimpinan instruksional dalam kalangan pengetua sekolah menengah di Negeri Pahang: Satu kajian kualitatif. Journal of Edupres, 1, 323-335. Retrieved from http://eprints.utm.my/17080/1/JOE-1-2011-039.pdf

[51] James, A. J. E., \& Balasandran, R. (2013). Kepimpinan instruksional: Satu panduan praktikal (2nd ed.). Kuala Lumpur: PTS Akademia.

[52] Kementerian Pendidikan Malaysia. (1982). Laporan jawatankuasa mengkaji taraf pendidikan di sekolah-sekolah. Kuala Lumpur.

[53] Kementerian Pendidikan Malaysia. (2007). Memperkasakan kepimpinan instruksional di sekolah (1st ed.). Kuala Lumpur: Bahagian Sekolah, Kementerian Pendidikan Malaysia.

[54] Kementerian Pendidikan Malaysia. (2012). Laporan Awal Pelan Pembangunan Pendidikan Malaysia 2013-2025. Kuala Lumpur.

[55] Kementerian Pendidikan Malaysia. (2013). Pelan Pembangunan Pendidikan Malaysia 2013-2025. Kuala Lumpur.

[56] Kementerian Pendidikan Malaysia. (2015). Pelan Pembangunan Pendidikan Malaysia 2013-2025: Laporan Tahunan 2014. Kuala Lumpur.

[57] Kis, A., \& Konan, N. (2014). A Meta-analysis of gender differences in terms of teacher views on the instructional leadership behavior of principals. Educational Sciences: Theory \& Practice, 14(6), 2139-2145. http://doi.org/10.12738/estp.2014.6.2307

[58] Krug, S. E. (1992). Instructional leadership: A constructivist perspective. Educational Administration Quarterly, 18(3).

[59] Lashway, L. (2003). Role of the school leader: Trends and issues. Washington, DC. Retrieved from http://vtcite.com/ vtcite/system/files/08.pdf

[60] Latip, M. (2007). Pelaksanaan kepemimpinan pengajaran di kalangan pengetua sekolah. In Seminar Penyelidikan Institut Perguruan Batu Lintang.

[61] Leithwood, K. (2012). School leadership, evidence-based decision making, and large-scale student assessment. In C. F. Webber \& J. L. Lupart (Eds.), Leading Student Assessment (pp. 17-39). New York and London: Springer Netherlands.

[62] Leithwood, K. A., \& Montgomery, D. J. (1982). The role of the elementary school principal in program improvement. Review of Educational Research, 52(3), 309-339.

[63] Leithwood, K., Harris, A., \& Hopkins, D. (2008). Seven strong claims about successful school leadership. School Leadership \& Management, 28(1), http://doi.org/10.1080/13632430701800060

[64] Leithwood, K., \& Jantzi, D. (2000). Principal and teacher leadership effects: A replication. School Leadership \& Management, 20(4), 415-434. http://doi.org/10.1080/13632430020003210

[65] Leithwood, K., \& Jantzi, D. (2005). A review of transformational school leadership research 1996-2005. Leadership \& Policy in Schools, 4(3), 177-199. http://doi.org/10.1080/15700760500244769

[66] Leithwood, K., Patten, S., \& Jantzi, D. (2010). Testing a conception of how school leadership influences student learning. Educational Administration Quarterly, 46(5), 671-706. http://doi.org/10.1177/0013161X10377347

[67] Marshall, K. (2003). Recovering from HSPS (Hyperactive Superficial Principal Syndrome): A progress report. Phi Delta Kappan, 84(9), 701-709.

Retrieved

from http://search.ebscohost.com/login.aspx?direct=true \&db=f5h\&AN=96 88289\&site $=$ ehost-live

[68] Marzano, R. J. (2003). What works in schools: Translating research into action. Alexxandria, VA: Association for Supervision and Curriculum Developmen (ASCD).

[69] Masitah, M. Y., \& Khaidir, A. M. (2015). The relationship between instructional leadership and self- efficacy in environmental education among Malaysian secondary school teachers. International Academic Research Journal of Social Science, 1(1), 41-50.
[70] Mohd, Y. I., \& Aziz, A. (2014). Model kepimimpinan pengajaran pengetua dan kompetensi pengajaran guru. Jurnal Kurikulum \& Pengajajran Asia Pasifik, 2(1), 11-25.

[71] Mohd, Z. I. (2009). Amalan kepimpinan instruksional pengetua sekolah menengah berprestasi tinggi dengan sekolah menengah berprestasi rendah di daerah Kota Setar Kedah Darul Aman. Universiti Utara Malaysia. Retrieved from Master Dissertation

[72] Mortimore, P. (1993). School effectiveness and the management of effective learning and teaching. School Effectiveness and School Improvement, 4(4), http://doi.org/10.1080/0924345930040404

[73] Murphy, J. F. (1990). Principal instructional leadership. In L. S. Lotto \& P. W. Thurston (Eds.), Advanced in educational administration: Changing perspectives on the school (Vol 1). Greenwoch: JAI Press.

[74] Nor, J. M., \& Haris, S. M. (2013). Principal's intructional leadership and teachers' work place well being: A comparative and relationship study between "sekolah menengah agama bantuan kerajaan" and "sekolah menengah agama rakyat”. In Seminar Kebangsaan kali ke IV Majlis Dekan Pendidikan IPTA 2013 (pp. 170-181). Universiti Islam Antarabangsa Malaysia http://doi.org/10.1007/s13398-014-0173-7.2

(UIAM).

[75] Performance Management and Delivery Unit (PEMANDU). (2010) Government transformation programme. Malaysia. Retrieved from http://www.pemandu.gov.my/gtp/upload/GTP_AR2010_Eng.pdf

[76] Pettiegrew, H. (2013). The perceptions of principal instructional leadership practices on 8th. grade Ohio Achievement Assessment (OAA). Cleveland State University.

[77] Purkey, S. C., \& Smith, M. S. (1983). Effective schools : A review. The Elementary School Journal, 83(4), 426-452.

[78] Rahimi, Y. M., \& Yusri, I. M. (2015). Sumbangan kepimpinan instruksional maya terhadap kompetensi pengajaran guru. In 3rd International Conference on Social Sceince Research (p. 11). Kuala Lumpur.

[79] Robinson, V. M. J., Lloyd, C. A., \& Rowe, K. J. (2008). The impact of leadership on student outcomes: An analysis of the differential effects of leadership types. Educational Administration Quarterly, 44(5), 635-674. http://doi.org/10.1177/0013161X08321509

[80] Shafinaz, A. M., Chua, Y. P., Hussein, A., \& Shahrin, A. (2008). Kecerdasan emosi dan kepimpinan instruksional pengetua sekolah. Pemimpin 11, 78-88.

[81] Sisman, M. (2016). Factors related to instructional leadership perception and effect of instructional leadership on organizational variables : A meta-analysis. Educational Sciences: Thoery \& Practice, 16(5), 1761-1787. http://doi.org/10.12738/estp.2016.5.0172

[82] Smith, S. C., \& Piele, P. K. (2006). School leadership: Handbook for excellence (4th ed.). University of Oregon: Corwin Press. Retrieved from file://C:/Users/Jannik/Documents/Citavi 5/Projects/Masterthesis/Citavi Attachments/635980887340415299.pdf

[83] Southworth, G. (2002). Instructional leadership in schools: Reflections and empirical evidence. School Leadership \& Management, 22(1), 73-91.

[84] Stronge, J. H. (1993). Defining the Principalship: Instructional Leaders or Middle manager. NASSP, 77(553), 1-7.

[85] Tirozzi, G. N. (2001). The artistry of leadership: The evolving role of the secondary school principal. Phi Delta Kappa International, 434-439.

[86] Volante, L., Cherubini, L., \& Drake, S. (2008). Examining factors that influence school administrators' responses to large-scale assessment. Canadian Journal of Educational Administration and Policy, (84).

[87] Waters, T., Marzano, R. J., \& McNulty, B. (2003). Balanced Leadership: What 30 years of research tells us about the effect of leadership on student achievement. A working paper. Aurora, CO. http://doi.org/10.1080/09243450512331383272

[88] Weber, J. R. (1996). Leading the instructional program. School Leadership, 253-278.

[89] Wilson, A. (2016). From professional practice to practical leader: Teacher leadership in professional learning c communities. International Journal of Teacher Leadership, 7(2), 45-62.

[90] Zakaria, O. (2016). Kepimpinan instruksional guru besar di sekolah kurang murid. Universiti Malaya. 


\section{AUTHOR'S PROFILE}

Roslizam Hassan, Faculty of Education, Universiti Teknologi Malaysia The area of expertise includes Educational Leadership, Instructional Leadership.

Jamilah Ahmad, Senior Lecturer, Faculty of Education, Universiti Teknologi Malaysia. The area of Expertise is Teaching and learning, Pedagogy and Education

Yusof Boon, Associate Professor, Senior Lecturer, Faculty of Education Universiti Teknologi Malaysia. The area of Expertise includes but not limited to Educational research. 